\title{
Microbial ecology of hydrocarbon-polluted coastal sediments
}

\author{
Robert Duran $^{1} \cdot$ Philippe Cuny $^{2} \cdot$ Patricia Bonin $^{2} \cdot$ Cristiana Cravo-Laureau $^{1}$
}

Received: 2 September 2015 / Accepted: 4 September 2015 /Published online: 18 September 2015

(C) Springer-Verlag Berlin Heidelberg 2015

Coastal shorelines suffer a variety of pollution injuries from both sides, from the sea, predominantly by crude oil from shipping and offshore mining, and from the land, principally through agricultural practices, urban wastewaters, and industrial activities. As a result, multi-pollution hot spots are found along shorelines, especially in estuaries and harbors. Microbial communities have evolved to adapt their metabolism to the presence of multi-contaminants (Duran et al. 2008; Gillan et al. 2005; Iannelli et al. 2012; Kaci et al. 2014; SabadiniSantos et al. 2014; Wang and Tam 2012). However, hydrocarbon compounds and crude oil-derived products are the most abundant pollutants, the more spectacular source being oil spill as illustrated by the recent catastrophe of Deepwater Horizon in 2010, the largest oil spill so far observed (Atlas and Hazen 2011). Although they are frequently found at unacceptably high concentrations, hydrocarbons are natural compounds, and thus, most of them can be biodegraded by the collective catabolic diversity of microorganisms (Duran and Goñi Urriza 2010; Head et al. 2006; Leahy and Colwell 1990; Miralles et al. 2007; Paisse et al. 2011; Paisse et al. 2010), particularly demonstrated in coastal marine ecosystems such as salt marshes with microbial mat structures (Bordenave et al. 2004a;

Responsible editor: Philippe Garrigues

Robert Duran

Robert.duran@univ-pau.fr

1 Equipe Environnement et Microbiologie, MELODY group, Université de Pau et des Pays de l'Adour, IPREM UMR CNRS 5254, BP 1155, 64013 Pau Cedex, France

2 Aix Marseille Université, CNRS/INSU, Université de Toulon, IRD, Mediterranean Institute of Oceanography UM 110, 13288 Marseille, France
Bordenave et al. 2008; Bordenave et al. 2007; Bordenave et al. 2004b), mangroves (Brito et al. 2009; Brito et al. 2006) and estuaries (Chronopoulou et al. 2013; Coulon et al. 2012). However, coastal marine sediments constitute particular ecosystems submitted to fluctuating oxygenation and redox conditions from the tidal cycles and burrowing activities of the macrofauna that in turn drive microbial degradation processes (Cravo-Laureau and Duran 2014). The biodegradation of hydrocarbon compounds in such oxic/anoxic oscillating environments still remains poorly understood (Cravo-Laureau et al. 2011; Cuny et al. 2011; Vitte et al. 2013; Vitte et al. 2011). The understanding of the particular microbes involved, their ecology, their genetic and enzymatic capacities, their interactions, as well as their functioning in the changing redox conditions, is crucial for the implementation of efficient bioremediation strategies (Goñi-Urriza et al. 2013; McGenity 2014). The DECAPAGE project (ANR CESA-2011-006 01; http:/ipremeem.univ-pau.fr/live/DECAPAGE), funded by the French National Agency for Research (ANR), was precisely devoted to understand the adaptation mechanisms driving the reorganization of bacterial communities in response to petroleum in coastal sediments. In this special issue, the scientists involved in the DECAPAGE project present their contribution for understanding the microbial ecology in hydrocarbon-polluted mudflat sediments. The special issue also includes articles from scientists involved in other projects and programs in order to enlarge the topic to diverse ecosystems, to different biological organization levels from microbial and macrobenthic communities to bacterial populations, and addressing remediation strategies as well. Thus, the 15 articles compiled in this special issue explore diverse facets of the microbial ecology of hydrocarbon-polluted coastal sediments. The article of Acosta-González et al. (2015) reviews the impact of the Prestige oil spill, an accident that occurred in 2002 at the 
Spanish Atlantic coast, on coastal environments with special emphasis on the microbial community aspects, responding to one of the primary questions arising when an oil spill catastrophe occurs: what we learn from the past (Goñi Urriza and Duran 2010) to combat oil pollution.

The description and characterization of bacterial communities in coastal environments also provide crucial information on the behavior of microbial communities in front of a contamination. The powerful resolution of high-throughput sequencing approaches allows the characterization of structural and metabolic changes of microbial communities in contaminated marine ecosystems. The comparison of microbial communities from marine sites with contrasted contamination levels described in Duran et al. (2015a) showed specific bacterial assemblages according to the type of contaminant. The study, focusing on Actinobacteria assemblage, revealed the ecological importance of Actinobacteria for maintaining both general biogeochemical functions through a "core" Actinobacteria community and specific roles associated with the presence of contaminants. Such information is pivotal for the implementation of efficient bioremediation processes in marine ecosystems.

Experimental ecology, based on mesocosm approaches, provides essential knowledge on microbial ecology and hydrocarbon biodegradation, essential transition from laboratory to field studies (Cravo-Laureau and Duran 2014; Kostka et al. 2014). In this issue, four papers use sophisticated mesocosm approaches mimicking as close as possible the environmental conditions to dissect the microbial assemblages involved in hydrocarbon degradation. Sanni et al. (2015) reveals the importance to combine culture-dependent and cultureindependent approaches to estimate the potential for natural attenuation in tidal mudflats. The study also reveals the importance of Oleibacter, Alcanivorax, Cycloclasticus, and Thalassolituus related species in hydrocarbon degradation. The organization of a hydrocarbon-degrading microbial assemblage is strongly influenced by environmental conditions as illustrated in this issue by mechanical reworking of sediments (Duran et al. 2015b) and oxygenation regimes (Militon et al. 2015), studies that demonstrated the complexity of bacterial interactions and revealed potential new hydrocarbondegrading candidates. The study focusing on sulfatereducing microorganisms (SRM) by Stauffert et al. (2014a) confirms the influence of environmental parameters, particularly the bioturbation activity of burrowing macrofauna such as Hediste diversicolor.

Although the influence of burrowing macrofauna on the structuration of microbial communities in oil-polluted sediments has been demonstrated (Cuny et al. 2007; Pischedda et al. 2011; Stauffert et al. 2015; Stauffert et al. 2013; Stauffert et al. 2014b), little is known on the effect of hydrocarbons on macrofaunal communities (Louati et al. 2014a; Louati et al. 2013). Four papers in this issue evaluated the impact of crude oil and polyaromatic hydrocarbons (PAHs) on macrofauna. Gilbert et al. (2014) showed that the macrofaunal community structure was not affected by an oil contamination in a historically hydrocarbon-contaminated sediment but the sedimentreworking activity was characterized by a deeper particle burial. In contrast, Ferrando et al. (2015) demonstrated the deleterious effect of crude oil on macrofaunal community structure and reworking activity in a pristine sediment without pollution history suggesting that macrofaunal species could serve as bioindicators of pollution. The paper by Louati et al. (2014b) confirms the negative impact of PAHs on macrofaunal communities and further demonstrates the capacity of bioremediation strategies (biostimulation and/ or bioaugmentation) to mitigate the effects of PAHs on macrofauna diversity. Such observation suggests strong links between microorganisms and macrofauna. The relationships between macrofaunal and microbial communities are discussed by Ben Said et al. (2015).

The isolation and characterization of new hydrocarbonoclastic bacteria are always useful for a better understanding of the bacterial hydrocarbon degradation mechanisms; particularly bacteria showing the capacity to degrade both $n$-alkanes and PAHs are of special interest as described by Guermouche M'rassi et al. (2015). Among hydrocarbon-degrading bacteria, Marinobacter related species, as true marine hydrocarbon bacteria, are efficient degraders of aliphatic and polycyclic aromatic hydrocarbons as well as acyclic isoprenoid compounds (Duran 2010). Bonin et al. (2015) showed the substrate specialization in lipid compounds and hydrocarbons of Marinobacter genus through analyzing the physiological capacities of 34 Marinobacter strains and the genomic analysis of 16 Marinobacter genomes. The horizontal gene transfer allows bacteria to acquire adaptive genes, particularly catabolic gene clusters for hydrocarbon degradation (De la Cruz and Davies 2000; Huang et al. 2009). In this issue, Abella et al. (2015) review the current knowledge on integrons in marine environments and demonstrate their implication in bacterial adaptive responses, especially in hydrocarbon and toxic metal contamination contexts.

Finally, two papers in this issue evaluate remediation strategies that use either dispersants (Cuny et al. 2015) for increasing hydrocarbon bioavailability or electron acceptors as substitute to oxygen (Brundrett et al. 2015). Cuny et al. (2015) demonstrated that the use of the dispersant accelerated hydrocarbon removal but had negative effect on the sediment-reworking activity by macrofauna, which was observed with no obvious effect on macrofauna diversity. Brundrett et al. (2015) showed that chlorate was efficient as oxygen to mineralize Macondo crude oil from the Deepwater Horizon oil spill in salt marshes, which is a promising remediation strategy preventing unwanted secondary impacts of nitrate amendments. 
The microbial ecology in sediments' coastal areas is extremely complex. Many questions remain to be elucidated such as the structure/function relationships and microbial interactions and networks (Cravo-Laureau and Duran 2014). The next-generation sequencing technologies combined with systems biology approaches are promising holistic approaches to elucidate the burning microbial ecology questions in order to open the black box of microbial processes involved in hydrocarbon degradation.

Acknowledgments We acknowledge the support of the French program ANR DECAPAGE (project ANR-CESA-505 2011-006 01). We would like to thank all partners of the DECAPAGE project for their useful discussions.

\section{References}

Abella J, Bielen A, Huang L, Delmont T, Vujaklija D, Duran R, Cagnon C (2015) Integron diversity in marine environments. Environ Sci Pollut Res Int: 1-10.

Acosta-González A, Martirani-von Abercron S-M, Rosselló-Móra R, Wittich R-M, Marqués S (2015) The effect of oil spills on the bacterial diversity and catabolic function in coastal sediments: a case study on the Prestige oil spill. Environ Sci Pollut Res Int: 1-15.

Atlas RM, Hazen TC (2011) Oil biodegradation and bioremediation: a tale of the two worst spills in US history. Environ Sci Technol 45: $6709-6715$

Ben Said O, Louati H, Soltani A, Preud'homme H, Cravo-Laureau C, Got P, Pringault O, Aissa P, Duran R (2015) Changes of benthic bacteria and meiofauna assemblages during bio-treatments of anthracenecontaminated sediments from Bizerta lagoon (Tunisia). Environ Sci Pollut Res Int: 1-13.

Bonin P, Vieira C, Grimaud R, Militon C, Cuny P, Lima O, Guasco S, Brussaard CPD, Michotey V (2015) Substrates specialization in lipid compounds and hydrocarbons of Marinobacter genus. Environ Sci Pollut Res Int

Bordenave S, Fourçans A, Blanchard S, Goñi MS, Caumette P, Duran R (2004a) Structure and functional analyses of bacterial communities changes in microbial mats following petroleum exposure. Ophelia 58:195-203

Bordenave S, Jézéquel R, Fourçans A, Budzinski H, Merlin FX, Fourel T, Goñi-Urriza M, Guyoneaud R, Grimaud R, Caumette P, Duran R (2004b) Degradation of the "Erika" oil. Aquat Living Resour 17: 261-267

Bordenave S, Goñi-Urriza MS, Caumette P, Duran R (2007) Effects of heavy fuel oil on the bacterial community structure of a pristine microbial mat. Appl Environ Microbiol 73:6089-6097

Bordenave S, Goñi-Urriza M, Vilette C, Blanchard S, Caumette P, Duran R (2008) Diversity of ring-hydroxylating dioxygenases in pristine and oil contaminated microbial mats at genomic and transcriptomic levels. Environ Microbiol 10:3201-3211

Brito EMS, Guyoneaud R, Goñi-Urriza M, Ranchou-Peyruse A, Verbaere A, Crapez MAC, Wasserman JCA, Duran R (2006) Characterization of hydrocarbonoclastic bacterial communities from mangrove sediments in Guanabara Bay, Brazil. Res Microbiol 157:752-762

Brito EMS, Duran R, Guyoneaud R, Goñi-Urriza M, García de Oteyza T, Crapez MAC, Aleluia I, Wasserman JCA (2009) A case study of in situ oil contamination in a mangrove swamp (Rio De Janeiro, Brazil). Mar Pollut Bull 58:418-423

Brundrett M, Horita J, Anderson T, Pardue J, Reible D, Jackson WA (2015) The use of chlorate, nitrate, and perchlorate to promote crude oil mineralization in salt marsh sediments. Environ Sci Pollut Res Int: 1-9.

Chronopoulou PM, Fahy A, Coulon F, Païssé S, Goñi-Urriza M, Peperzak L, Acuña Alvarez L, McKew BA, Lawson T, Timmis KN, Duran R, Underwood GJC, McGenity TJ (2013) Impact of a simulated oil spill on benthic phototrophs and nitrogen-fixing bacteria in mudflat mesocosms. Environ Microbiol 15:242-252

Coulon F, Chronopoulou PM, Fahy A, Païssé S, Goñi-Urriza M, Peperzak L, Alvarez LA, McKew BA, Brussaard CPD, Underwood GJC, Timmis KN, Duran R, McGenity TJ (2012) Central role of dynamic tidal biofilms dominated by aerobic hydrocarbonoclastic bacteria and diatoms in the biodegradation of hydrocarbons in coastal mudflats. Appl Environ Microbiol 78: 3638-3648

Cravo-Laureau C, Hernandez-Raquet G, Vitte I, Jézéquel R, Bellet V, Godon JJ, Caumette P, Balaguer P, Duran R (2011) Role of environmental fluctuations and microbial diversity in degradation of hydrocarbons in contaminated sludge. Res Microbiol 162:889-895

Cravo-Laureau C, Duran R (2014) Marine coastal sediments microbial hydrocarbon degradation processes: contribution of experimental ecology in the omics'era. Front Microbiol 5:39

Cuny P, Miralles G, Cornet-Barthaux V, Acquaviva M, Stora G, Grossi V, Gilbert F (2007) Influence of bioturbation by the polychaete Nereis diversicolor on the structure of bacterial communities in oil contaminated coastal sediments. Mar Pollut Bull 54:452-459

Cuny P, Cravo-Laureau C, Grossi V, Gilbert F, Militon C (2011) Biodegradation of hydrocarbons in bioturbated marine sediments. In: Koukkou A-IE (ed) Microbial bioremediation of non-metals: current research. Caister Academic Press, UK, pp 55-92

Cuny P, Gilbert F, Militon C, Stora G, Bonin P, Michotey V, Guasco S, Duboscq K, Cagnon C, Jézéquel R, Cravo-Laureau C, Duran R (2015) Use of dispersant in mudflat oil-contaminated sediment: behavior and effects of dispersed oil on micro- and macrobenthos. Environ Sci Pollut Res Int: 1-7.

De la Cruz F, Davies J (2000) Horizontal gene transfer and the origin of species: lessons from bacteria. Trends Microbiol 8:128-133

Duran R, Ranchou-Peyruse M, Menuet V, Monperrus M, Bareille G, Goni MS, Salvado JC, Amouroux D, Guyoneaud R, Donard OFX, Caumette P (2008) Mercury methylation by a microbial community from sediments of the Adour Estuary (Bay of Biscay, France). Environ Pollut 156:951-958

Duran R (2010) Marinobacter - microbes and communities utilizing hydrocarbons, oils and lipids. In: Timmis KN (ed) Handbook of hydrocarbon and lipid microbiology. Springer, Berlin Heidelberg, pp $1725-1735$

Duran R, Goñi Urriza MS (2010) Impact of pollution on microbial mats. Microbes and communities utilizing hydrocarbons, oils and lipids. In: Timmis KN (ed) Handbook of hydrocarbon and lipid microbiology. Springer, Berlin Heidelberg, pp 2339-2348

Duran R, Bielen A, Paradžik T, Gassie C, Pustijanac E, Cagnon C, Hamer B, Vujaklija D (2015a) Exploring Actinobacteria assemblages in coastal marine sediments under contrasted Human influences in the West Istria Sea, Croatia. Environ Sci Pollut Res Int.

Duran R, Bonin P, Jezequel R, Dubosc K, Gassie C, Terrisse F, Abella J, Cagnon C, Militon C, Michotey V, Gilbert F, Cuny P, CravoLaureau C (2015b) Effect of physical sediments reworking on hydrocarbon degradation and bacterial community structure in marine coastal sediments. Environ Sci Pollut Res Int.

Ferrando A, Gonzalez E, Franco M, Commendatore M, Nievas M, Militon C, Stora G, Gilbert F, Esteves J, Cuny P (2015) Oil spill effects on macrofaunal communities and bioturbation of pristine marine sediments (Caleta Valdés, Patagonia, Argentina): experimental evidence of low resistance capacities of benthic systems without history of pollution. Environ Sci Pollut Res Int: 1-13.

Gilbert F, Stora G, Cuny P (2014) Functional response of an adapted subtidal macrobenthic community to an oil spill: macrobenthic 
structure and bioturbation activity over time throughout an 18 month field experiment. Environ Sci Pollut Res Int: 1-9.

Gillan DC, Danis B, Pernet P, Joly G, Dubois P (2005) Structure of sediment-associated microbial communities along a heavy-metal contamination gradient in the marine environment. Appl Environ Microbiol 71:679-690

Goñi Urriza MS, Duran R (2010) The Gulf oil spill: we have been here before. Can we learn from the past? Journal of Cosmology 8: 2006-2008

Goñi-Urriza M, Cravo-Laureau C, Duran R (2013) Microbial bioremediation of aquatic environments. In: Blaise C, Férard J-F (eds) Encyclopedia of aquatic ecotoxicology. Springer, Netherlands, pp 709-720

Guermouche M'rassi A, Bensalah F, Gury J, Duran R (2015) Isolation and characterization of different bacterial strains for bioremediation of n-alkanes and polycyclic aromatic hydrocarbons. Environ Sci Pollut Res Int: 1-15.

Head IM, Jones DM, Roling WFM (2006) Marine microorganisms make a meal of oil. Nat Rev Microbiol 4:173-182

Huang L, Cagnon C, Caumette P, Duran R (2009) First gene cassettes of integrons as targets in finding adaptive genes in metagenomes. Appl Environ Microbiol 75:3823-3825

Iannelli R, Bianchi V, Macci C, Peruzzi E, Chiellini C, Petroni G, Masciandaro G (2012) Assessment of pollution impact on biological activity and structure of seabed bacterial communities in the Port of Livorno (Italy). Sci Total Environ 426:56-64

Kaci A, Petit F, Lesueur P, Boust D, Vrel A, Berthe T (2014) Distinct diversity of the czcA gene in two sedimentary horizons from a contaminated estuarine core. Environ Sci Pollut Res Int 21:10787-10802

Kostka JE, Teske A, Joye SB, Head IM (2014) The metabolic pathways and environmental controls of hydrocarbon biodegradation in marine ecosystems. Front Microbiol 5

Leahy JG, Colwell RR (1990) Microbial-degradation of hydrocarbons in the environment. Microbiol Rev 54:305-315

Louati H, Ben Said O, Soltani A, Got P, Mahmoudi E, Cravo-Laureau C, Duran R, Aissa P, Pringault O (2013) The roles of biological interactions and pollutant contamination in shaping microbial benthic community structure. Chemosphere 93:2535-2546

Louati H, Ben Said O, Soltani A, Cravo-Laureau C, Preud'Homme H, Duran R, Aissa P, Mahmoudi E, Pringault O (2014a) Impacts of bioremediation schemes for the mitigation of a low-dose anthracene contamination on free-living marine benthic nematodes. Ecotoxicology 23:201-212

Louati H, Said O, Soltani A, Cravo-Laureau C, Duran R, Aissa P, Mahmoudi E, Pringault O (2014b) Responses of a free-living benthic marine nematode community to bioremediation of a PAH mixture. Environ Sci Pollut Res Int: 1-12.

McGenity TJ (2014) Hydrocarbon biodegradation in intertidal wetland sediments. Curr Opin Biotechnol 27:46-54

Militon C, Jézéquel R, Gilbert F, Corsellis Y, Sylvi L, Cravo-Laureau C, Duran R, Cuny P (2015) Dynamics of bacterial assemblages and removal of polycyclic aromatic hydrocarbons in oil-contaminated coastal marine sediments subjected to contrasted oxygen regimes. Environ Sci Pollut Res Int,
Miralles G, Grossi V, Acquaviva M, Duran R, Claude Bertrand J, Cuny P (2007) Alkane biodegradation and dynamics of phylogenetic subgroups of sulfate-reducing bacteria in an anoxic coastal marine sediment artificially contaminated with oil. Chemosphere 68: $1327-1334$

Paisse S, Goni-Urriza M, Coulon F, Duran R (2010) How a bacterial community originating from a contaminated coastal sediment responds to an oil input. Microb Ecol 60:394-405

Paisse S, Duran R, Coulon F, Goñi-Urriza M (2011) Are alkane hydroxylase genes (alkB) relevant to assess petroleum bioremediation processes in chronically polluted coastal sediments? Appl Microbiol Biotechnol 92:835-844

Pischedda L, Militon C, Gilbert F, Cuny P (2011) Characterization of specificity of bacterial community structure within the burrow environment of the marine polychaete Hediste (Nereis) diversicolor. Res Microbiol 162:1033-1042

Sabadini-Santos E, da Silva TS, Lopes-Rosa TD, Mendonca-Filho JG, Santelli RE, Crapez MAC (2014) Microbial activities and bioavailable concentrations of $\mathrm{Cu}, \mathrm{Zn}$, and $\mathrm{Pb}$ in sediments from a tropic and eutrothicated bay. Water Air Soil Pollut 225

Sanni G, Coulon F, McGenity T (2015) Dynamics and distribution of bacterial and archaeal communities in oil-contaminated temperate coastal mudflat mesocosms. Environ Sci Pollut Res Int: $1-18$.

Stauffert M, Cravo-Laureau C, Jézéquel R, Barantal S, Cuny P, Gilbert F, Cagnon C, Militon C, Amouroux D, Mahdaoui F, Bouyssiere B, Stora G, Merlin FX, Duran R (2013) Impact of oil on bacterial community structure in bioturbated sediments. PLoS One 8

Stauffert M, Cravo-Laureau C, Duran R (2014a) Dynamic of sulphatereducing microorganisms in petroleum-contaminated marine sediments inhabited by the polychaete Hediste diversicolor. Environ Sci Pollut Res Int.

Stauffert M, Duran R, Gassie C, Cravo-Laureau C (2014b) Response of archaeal communities to oil spill in bioturbated mudflat sediments. Microb Ecol 67:108-119

Stauffert M, Cravo-Laureau C, Duran R (2015) Structure of hydrocarbonoclastic nitrate-reducing bacterial communities in bioturbated coastal marine sediments. FEMS Microbiol Ecol 89: 580-593

Vitte I, Duran R, Jézéquel R, Caumette P, Cravo-Laureau C (2011) Effect of oxic/anoxic switches on bacterial communities and PAH biodegradation in an oil-contaminated sludge. Environ Sci Pollut Res Int 18:1022-1032

Vitte I, Duran R, Hernandez-Raquet G, Mounier J, Jézéquel R, Bellet V, Balaguer P, Caumette P, Cravo-Laureau C (2013) Dynamics of metabolically active bacterial communities involved in PAH and toxicity elimination from oil-contaminated sludge during anoxic/oxic oscillations. Appl Microbiol Biotechnol 97:4199-4211

Wang Y-F, Tam NF-Y (2012) Natural attenuation of contaminated marine sediments from an old floating dock part II: changes of sediment microbial community structure and its relationship with environmental variables. Sci Total Environ 423:95-103 


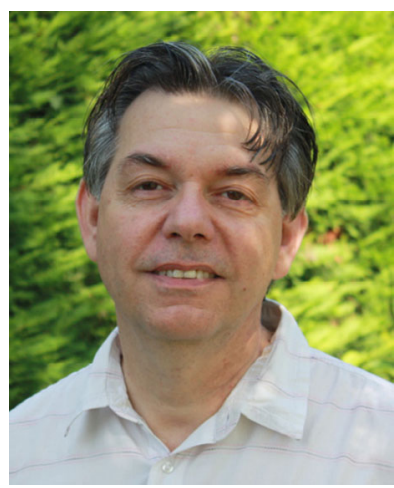

Robert Duran is Professor in Environmental Molecular Microbiology at Pau University. He is leading a research team (Equipe Environnement et Microbiologie) in the Institute for Analytical Sciences and Physico-Chemistry for Environment and Materials (IPREM), a CNRS-UPPA (University of Pau and Pays de l'Adour) joined unit. He has been working for 20 years in environmental microbiology and molecular microbiology research. His current research focuses on microbial ecology and diversity, with an emphasis on extreme, polluted, and estuarine and coastal ecosystems. Relevant recent discoveries include the characterization of the taxonomic and functional microbial diversity in extreme and contaminated ecosystems: behavior of sulfate-reducing bacteria populations in acid mine drainage and microbial mats according to the fluctuation of environmental parameters, the diversity of ring hydroxylating dioxygenases in polluted microbial mats, and the organization of hydrocarbon-degrading prokaryotic communities in mudflat sediments. He is PI of the ANR DECAPAGE project (http://iprem-eem.univpau.fr/live/DECAPAGE) aiming to understand the microbial ecology of hydrocarbon-polluted coastal sediments.

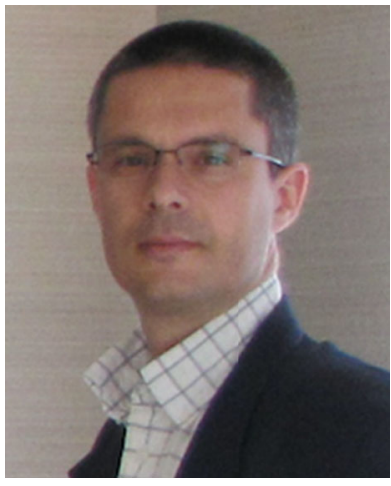

Philippe Cuny is Professor in Marine Microbial Ecology at the Mediterranean Institute of Oceanography (MIO, Aix-Marseille University). His current research interest is focused on the study of the microbial community dynamics and hydrocarbon biodegradation activity in marine sediments and hypersaline environments submitted to chronic or massive oil inputs. Special attention is paid to the interactions between microand macroorganisms that strongly influence the fate of hydrocarbons in bioturbated marine sediments. In particular, the effects of bioturbationinduced redox oscillations on the functioning of the hydrocarbonoclastic communities are studied. The conclusions of the recent works highlight the need of a more holistic and integrative ecological approach in order to understand and predict the fate of oil in marine ecosystems.

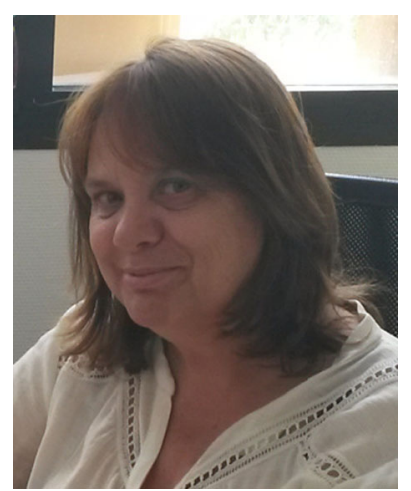

Patricia Bonin is CNRS senior scientist at Mediterranean Institute of Oceanography in CNRS-AixMarseille University joined Unit. She is head leader of a research team (Equipe Microbiologie Environnementale et Biotechnologie). She has 25 years research experience in microbial ecology of hydrocarbon-polluted coastal sediments with particular expertise on nitrogen cycling and microbial ecology associated bacterial processes at the aerobicanaerobic interfaces: sediments or microbial mats. Her multidisciplinary approaches, at the interface of biogeochemistry and microbial ecology, drove significant advances in the knowledge of the ecology of this cycle including the coupling between aerobic and anaerobic processes and the behavior of organic matter at aerobic-anaerobic interfaces or interactions between nitrogen and metallic cycling.

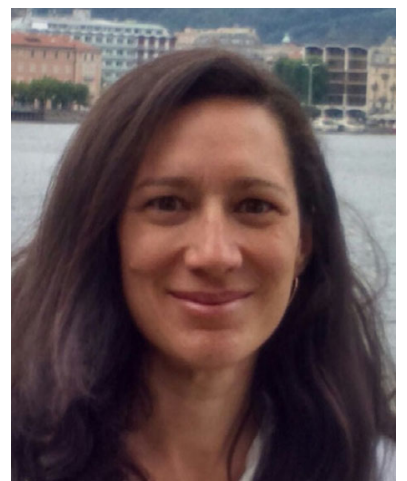

Cristiana Cravo-Laureau is Associate Professor in Environmental Microbiology at Pau University. She has special interest in investigating the involvement of the microorganisms in the biogeochemical cycles and their role in pollutant degradation (natural environments and pure strains). She focuses on the role of microorganisms in hydrocarbon degradation in anoxic polluted environments. She has isolated and characterized hydrocarbonoclastic sulfatereducing strains. Her research also deals with aerobic and anaerobic communities involved in biodegradation of different oil-polluted ecosystems. She also expanded her research interests to the impact of oxic/anoxic oscillations on microbial communities and hydrocarbon degradation, and the influence of oscillations on anaerobic metabolisms. 